April 2012

\title{
Studying Mass Violence: Pitfalls, Problems, and Promises
}

Uğur Ümit Üngör

Follow this and additional works at: https://digitalcommons.usf.edu/gsp

\section{Recommended Citation}

Üngör, Uğur Ümit (2012) "Studying Mass Violence: Pitfalls, Problems, and Promises," Genocide Studies and Prevention: An International Journal: Vol. 7: Iss. 1: Article 8.

Available at: https://digitalcommons.usf.edu/gsp/vol7/iss1/8

This Articles is brought to you for free and open access by the Open Access Journals at Digital Commons @ University of South Florida. It has been accepted for inclusion in Genocide Studies and Prevention: An International Journal by an authorized editor of Digital Commons @ University of South Florida. For more information, please contact digitalcommons@usf.edu. 


\section{Studying Mass Violence: Pitfalls, Problems, and Promises}

\section{Uğur Ümit Üngör \\ Utrecht University and Institute for War and Genocide Studies, Amsterdam}

This article examines some of the main pitfalls, problems, and promises of genocide research. It argues that genocide is a viable academic concept if protected from moral, legal, political, and emotional constraints. It should be approached in a dispassionate, amoral, non-juridical, and apolitical way. The article further discusses a model for understanding genocide that identifies three levels of analysis: the interstate pressures of the global state system and the influence of crises and war; the intrastate context of radical ideology, state power, and the dynamic of the genocidal process; and the micro-level conditions that enable the involvement of individual actors in violence.

Key words: genocide, approaches, theoretical model, conceptualization

"The century of Einstein and Planck was also the century of Hitler."

-Vassili Grossman, Life and Fate

\section{Introduction}

Genocide can be defined as a complex process of systematic persecution and annihilation directed at a particular group of people by a government. In the twentieth century, between 40 and 60 million people fell victim to deliberate genocidal policies. ${ }^{1}$ The twenty-first century began not much better, with genocidal episodes in Darfur and the Democratic Republic of Congo. We can speak of genocide when individuals are targeted for persecution and murder on the basis of their presumed or imputed membership in a group, rather than for any reason relating to their individual characteristics or their participation in certain acts. Although it makes little sense to work with victim minima, we can state that a genocidal process always involves a society at large and that genocide often destroys a significant-often critical-part of the affected community or communities. Arguably, genocidal processes are particularly malicious and destructive because they target all members of a group, mostly innocent and defenseless people who are persecuted and killed regardless of their behavior. The term "genocide" always denotes a brutal and colossal collective criminality. For this reason, the phenomenon of genocide is distinct from other forms of mass violence, such as war, civil war, or massacre. ${ }^{2}$

The term "genocide" was coined by the Polish-Jewish lawyer Raphael Lemkin (1900-1959). While attending law school at the University of L'viv (Lwów/Lemberg), Lemkin became interested in why international law had been unable to curb collective violence by states. He had studied massacres, and became convinced that governments should not be allowed to harm unarmed civilians. During World War II, Lemkin introduced the new concept of genocide, a neologism formed from the Greek genos ("people" or "race") and the Latin caedere ("to kill"). Lemkin defined genocide in 1944 as "a coordinated plan of different actions aiming at the destruction of essential foundations of the life of national groups, with the aim of annihilating the groups themselves." ${ }^{3}$ After 
his death in 1959, the term fell into disuse. In the 1970s, however, historians and social scientists rediscovered the concept and published the first academic studies on genocide. Since then, the number of publications on genocide has continued to grow, and today genocide studies is a respectable academic specialty with its own journals and research institutes in North America, Europe, Australia, and South America. ${ }^{4}$

The central question in genocide studies, How can we explain the fact that genocidal violence has occurred in culturally, technologically, and politically different societies?, has three sub-questions. First, what are the causes of a genocidal process? Or, how does the process of systematically destroying a category of people begin? Second, how does a genocidal process develop? There are strong indications that when such a process has been set in motion, it develops its own dynamic; how exactly does that dynamic evolve from the individual to the most collective level? Finally, what are the consequences of genocide? How do perpetrators, victims, and third parties continue to live after genocide? How do they process the traumatic events-or not? Much useful research has examined the evolution of separate genocides, such as the destruction of the Ottoman Armenians in 1915, the Holocaust, and the genocides in Cambodia (1975-1979), Rwanda (1994), and Bosnia (during the civil wars in the former Yugoslavia). We also know a great deal about specific aspects of genocidal processes: research has investigated how a fairly "normal" civil society turns into a persecutory society, the motives of ordinary killers, the power and effect of charismatic leaders, and the gender aspects of violence, among other issues. In this article, I discuss two themes related to genocide studies: the positionality of the scholar and a model for genocide analysis.

\section{Pitfalls and Problems}

The study of genocide has never generated consensus among students of the phenomenon. Some colleagues have even rejected the use of the word, citing politicization and lack of complexity as sources of misunderstanding. ${ }^{5}$ These are laudable concerns, but I believe we should preserve the concept, provided that we remain vigilant with respect to four perspectives: emotional, moral, legal, and political approaches.

First, let us consider the emotional constraints of genocide studies. All social research operates amidst the tension between involvement and detachment. As a general problem in the academy it has been dealt with at some length, and the study of violence is particularly relevant from the perspective of involvement and detachment. ${ }^{6}$ Many people find the topic intrinsically repulsive and react with strong condemnatory emotions. Although a certain amount of passion and involvement can determine a scholar's choice to study this topic, a great deal of detachment is necessary to sift through multitudes of documents and memoirs describing very intimate details of killing. Iris Chang's suicide, reportedly suffering from depression due to research on Japanese war crimes in China, might be an extreme example of excessive involvement. ${ }^{7}$ But even a seasoned researcher such as Robert J. Lifton confessed in the introduction to his book The Nazi Doctors that during the research process he had "nightmares about Auschwitz, sometimes involving my wife and children." 8 All in all, intensive research on violence can be straining when one is emotionally involved, and detachment remains important.

To illustrate how emotions interfere in genocide research, let us turn to empathy. Empathy is the capacity to recognize and, to some extent, share other human beings' feelings. It comprises the cognitive and affective process of "the inner experience of sharing in and comprehending the momentary psychological state of another person." 
In other words, emotions can be contagious. Anyone studying genocide cannot help but feel intense anger and hatred toward genocide and its perpetrators. This is a consequence of empathy: the real, existing emotions of the victim group contaminate the scholar. A personal example can elucidate this point. In the summer of 2007, I was featured in the documentary Land of our Grandparents, during which time I traveled to Eastern Turkey to trace the life of genocide survivor Vahram Goekjian, whose moving memoir I had read. ${ }^{10}$ In the documentary, we encounter a group of Turks partying in a place that was the site of a massacre in 1915 and I make a rancorous comment. Many viewers found this an unnecessary expression of acrimony, even wrath. Even I found my response unduly overweening when I watched the documentary much later, but after some reflection I now understand why I made the comment; as a result of empathy, the emotions of the victim group (Armenians) had deeply affected me. Indeed, Armenian audiences that watched the documentary understood me quite well, but for most viewers I came across as exceedingly emotional. For this reason, genocide studies is an isolating experience; the more one is absorbed into the material, the more one is drawn into these emotions through empathy. This process can lead to a certain loneliness, the feeling of not being understood by most people, and even professional deformations such as the development of an esoteric sense of black humor, which again isolates the genocide scholar further from mainstream society. ${ }^{11}$

A good way to think about involvement and detachment is the axis of tension between sacralization and trivialization. These two opposing forces can best be seen as poles on a continuum, and genocide scholars should maintain vigilance against both. At the one extreme, there is sacralization: victim activists sometimes mystify the phenomenon as an inexplicable horror that we cannot possibly fathom. Their history is sacred, they enjoy moral immunity, and the memory of their genocide has indeed been made into a religion by some. Their visits to sites such as death camps resemble pilgrimages as though they are out to catch some historical aura. This kind of approach is perfectly understandable from their perspective, but it carries some risks too. It places taboos on complex and ambivalent questions and does not help us better understand genocide. At the other end of the continuum there is trivialization. Spurious associations lead to the inflation of the concept and banalize it. For example, genocide has been applied to phenomena as disparate as the spread of AIDS, the 2003 American invasion of Iraq, postcolonial immigration to Britain, and Hurricane Katrina. At its most pernicious, trivialization includes deliberate genocide denial.

A second pitfall is moralization. Most people, but even some scholars, think about genocide in terms of good versus evil. Indeed, many books on genocide include the word "evil" in their main titles, usually coupled with a harrowing picture of skulls on the book cover. But a manicheistic divide between purely evil perpetrators and purely good victims is not at all helpful in explaining processes of mass violence. The myth of pure evil is a form of pre-scientific thought with a strong religious overtone. ${ }^{12}$ Popular representations of genocide often stagnate at this level of imagery. For example, a Channel 5 documentary titled The Most Evil Men and Women in History contains footage on Nero, Vlad Tepeş the Impaler, King John, Ivan the Terrible, Attila the Hun, Rasputin, Hitler, Pol Pot, and Idi Amin. ${ }^{13}$ The accompanying book reads, "There are some evil people in this world, when you think about the killing, torturing, bombing and maiming and this book covers it all."14 The example of Vlad Tepeş's violence against enemies and prisoners of war contains only images of cruelty: "He was a fan of various forms of 
torture including disembowelling and rectal and facial impalement. Vlad the Impaler tortured thousands while he ate and drank among the corpses." 15 But in the same breath, Stalin's "evil" is then interpreted as a matter of magnitude. ${ }^{16}$ Secular political leaders are portrayed as devils incarnate.

The imagery of evil is so powerful that it percolates into scholarship. Professional historians also sometimes find it difficult to avoid the pitfall of moralization. Simon Sebag Montefiore's Monsters: History's Most Evil Men and Women treats the following persons: Caligula, Richard III, Adolf Eichmann, Joseph Stalin, Pol Pot, Charles Manson, Herman Cortes, Hitler, Al Capone, Lavrenti Beria, Lucrezia Borgia, Nicolae Ceauşescu, Vlad the Impaler, Saddam Hussein, Simon de Montfort, Pablo Escobar, Ivan the Terrible, Genghis Khan, Idi Amin, Attila the Hun, Josef Mengele, Heinrich Himmler, Mao Zedong, Osama bin Laden, Kim Il Sung, Slobodan Milošević, Empress Cixi, and Tomas de Torquemeda. ${ }^{17}$ By lumping disparate political leaders together into a single pantheon of evil, both books are deeply ahistorical and asociological in their juxtapositions. The media's depiction of ongoing political violence, which profoundly shapes popular perceptions of violence, is no more sophisticated. Whereas violent individuals such as suicide terrorists, rampage shooters, or dictators are often seen as evil incarnate, when groups such as paramilitary units, political parties, or even entire societies descend into violence, this descent is often attributed to madness or some other collective psychiatric disorder. ${ }^{18}$ Moralistic approaches to genocide only serve to strengthen this kind of thought and do not add anything substantial to our understanding of it.

There can be no doubt that genocide is a crime and its perpetrators are criminals. Nevertheless, a third approach that we should try to avoid is the legalistic one. In legal practice, which at the international level is closely concerned with genocide, the objective is not necessarily to find out the causes and mechanisms of genocide but to prosecute and convict people. We should avoid the overuse of terms such as "crime," "criminal(s)," "punishment," "blame," and especially "guilt." In a lucid essay, the Dutch sociologist Van Benthem van den Bergh discussed the question of guilt as a means of intellectual orientation. He argued that the judicial system assumes that the individual and the society are two different realities, and he further noted that the courts that judge the criminals are not part of the human structures of that same society. An individual (or group of individuals) is accused of an act, and he or she must be judged as guilty or not guilty. Law does not concern itself with the nature of relationships between people or complex long-term processes, and it is purely interested in qualifying a single act and isolating it in a person. (Social science, on the other hand, looks at interpersonal or intergroup relations and treats individuals as intersection points of complex relational vectors.) Establishing a perpetrator's guilt is taken to mean that the cause of violence is a certain amount of evil in that perpetrator (a reification or personification of evil) and that the search for other causes can be terminated. ${ }^{19}$ This binary thought process sustains monocausality and leads to often-heard debates such as "was it genocide or not?" All in all, guilt and blame are not helpful points of departure for understanding genocidal processes.

Furthermore, legal responses to genocide are much more a product of politics and compromise than scholarly ones generally are. At the 1945 Nuremberg trials, significant concessions were awarded to the Soviet Union, whose prosecutors and judges such as Andrey Vyshinskiy, Roman Rudenko, Lev Sheinin, and Iona Nikitchenko had been up to their knees in blood during the 1930s. At Nuremberg, Stalin's juridical accomplices 
succeeded in obscuring the true nature of the Soviet massacre of Polish military and civilian elites, in which some were even personally complicit. ${ }^{20}$ After the Cold War, as hopes of an international human rights regime rose, some aspects of international law did not change. It was not an absolute, moral yardstick but an outcome of compromises struck between perpetrator elites and third parties. For example, when Radovan Karadzić was arraigned at the International Criminal Tribunal for the former Yugoslavia (ICTY), he claimed that US envoy Richard Holbrooke promised him immunity from prosecution if he withdrew from politics. ${ }^{21}$ Holbrooke passed away in 2010 and carried the truth to the grave, and we will probably never know the details. But Carla del Ponte hints at the existence of such deals as well in her unvarnished memoir of her tenure as prosecutor at the ICTY.22 Legal responses to genocide lack relative autonomy from power and do not offer a useful mode of orientation.

Finally, the fourth, and perhaps most important, danger that looms over genocide research is politics. Lobbyists, identity politics, activism and advocacy groups, and especially states use the concept not in a scholarly way but as a politischer Kampfbegriff (political combat concept) as hollow rhetoric. They have a vested interest in misrepresenting the truth and they often operate with legal and moral agendas. Political violence is politically very sensitive. The quintessential example of how lasting the damage is that genocide generates is the Turkish-Armenian conflict. Almost a full century after the event, group relations between these two neighboring ethnic groups are bitterly tense, both at the informal level and the formal, interstate level. Scholarship on the genocide is deeply politicized and only in recent years has steered away from partisanship and reached a modicum of normality. ${ }^{23}$ Politicization originates from all directions. Victim group activists demand genocide recognition not only because of the caedere aspect of the concept (i.e., the violence itself) but also because of the genos dimension of genocide (i.e., the collective nature of the violence). The victims often believe that they have been destroyed as a nation. Hence, recognition confirms group identity and acknowledges and reinstates the group's membership in a global family of nations. ${ }^{24}$ Critics, opposition groups, and the Left also engage in politicization; decades of fellow traveling with the Soviet Union testifies to this. But even after the collapse of communism, the Left's response to mass violence has not always been prudent. An excellent example is Marko Attila Hoare's devastating analysis of how left-wing European revisionists, by championing the Milošević regime as Europe's last "socialist" government, abandoned its Yugoslav victims and failed to respond appropriately to the violence. ${ }^{25}$ The politics of genocide are also embedded in a dense international force field in which genocide is abused as a diplomatic trump card. A clear example of international hypocrisy in denouncing genocide was the treatment of Kurds in the late 1980s and early 1990s in Turkey and Iraq. Whereas the Anfal campaign in Iraq, which cost approximately 150,000 Kurds their lives, was vigorously denounced, a deafening silence reigned regarding the Turkish army's blanket destruction of 3,000 Kurdish villages across the border. The diplomacy of genocide stems mostly from geopolitical interests between allies and enemies. ${ }^{26}$

The main catalyst in the politicization of genocide is the state. For some states, genocide denial is part and parcel of their collective identity process or national security concepts. Robert Hayden pointed out that "genocide has been a tool for building a number of nation states that are now honorable members of the world community." ${ }^{27}$ The identity politics and genocide denial of states that enjoy global legitimacy manifest themselves when governments, discontented with scholars searching for "skeletons in 
the closet," deny access to archival collections and libraries or prohibit them from conducting field work. The opposite situation is also possible: governments might try to foster or manipulate research by funding politically useful research by pushing for the establishment of academic chairs at home or abroad or by offering scholarships. Examples include both the Turkish and Armenian governments' manipulation of research on the Armenian Genocide, Israel's sacralization and monopolization of Jewish victimhood in the Holocaust, Iran's willingness to sponsor Holocaust denial, the former Ukrainian government's official declaration of the 1932-1933 famine as genocide, and the Rwandan government's exclusion of Hutu from the category of Rwandan genocide victims. ${ }^{28}$ This dense political and moral field has affected scholarship in quite fundamental ways. For this reason, Max Weber's classical distinction between politics as a vocation and science as a vocation should be written in stone for genocide scholars.

Victor Hugo famously said "If a man is killed in Paris, it is a murder; the throats of fifty thousand people are cut in the East, and it is a question." ${ }^{29}$ Although politicization has not (and will never be) surmounted, genocide studies has managed to overcome this kind of orientalism and methodological racism in the study of mass violence. It is to the credit of genocide scholars that orientalist approaches to violence have been subdued. Too often, génocidaires outside of Europe have been romanticized as products of ostensibly brutal cultures. Moreover, modern political crimes have been attributed to inherently evil crooks with large moustaches, living in exotic areas such as the Balkans and the Caucasus and possessed by oriental despotism and barbaric tribalism. For example, in accounts of the Armenian Genocide, the perpetrators, from the organizing elites to the rank-and-file executioners, have too often figured as evil faceless killers, undifferentiated and unexplained. The perpetrators appear in the Anatolian killing fields ex nihilo and murder people for no apparent reason other than innate (Turkish or Islamic) cruelty and malignance. These kinds of caricatures not only romanticize the perpetrators but play down the experiences of the victims. "The death of one man is a tragedy, the death of a million is a statistic." This harrowing quote, commonly (and probably wrongfully) attributed to Stalin, was the norm in orientalist views of genocide, in which the victims were not individuals but statistics. After all, they were only replaceable and expendable masses of illiterate peasants, anonymous villagers, or invisible subalterns anyway. Implicitly racist biases such as these continue to be undermined in research on mass violence, in which individual victims and perpetrators are taken seriously. Genocide studies needs to continue to reject essentialist platitudes and treat each and every individual and group as actors in a power struggle.

All in all, genocide research must strive to be dispassionate, amoral, non-juridical, and apolitical. Genocide can be studied, if not objectively and impartially, with due scholarly care.

\section{Promises}

A recent, profound, subtle, and nuanced study of genocidal violence is Jacques Semelin's Purify and Destroy: The Political Uses of Massacre and Genocide. ${ }^{30}$ The book is eminently interdisciplinary, covers a broad chronological and geographical perspective, and successfully integrates different theories. The tone is detached and the book has well-planned and effective moments of rest as well as acceleration. Semelin focuses on three cases by asking the following question: What did Germany in the 1930s, Yugoslavia in the late 1980s, and Rwanda in the early 1990s have in common that each came to such horrific violence? 
Semelin unfolds his model from the strong core concept of "imaginary," a noun that comprises the totality of ideas, emotions, and images that a social group or society has about itself. It is the definition of the "us," the in-group. The social imaginary is a socio-affective process subject to manipulation by political elites. This construct is continuously shaped by politicians and other prominent public figures. Semelin discusses how, in times of crisis, politicians increasingly come to forge this imaginary around three themes: identity, purity, and security. The first theme refers to identity politics, a form of politics that revolves around the self-interest of a self-proclaimed identity group, often on ethnic, religious, or racial grounds. The objective of identity politics is to define and elevate the in-group and to fuel polarization between the in-group and despised others. Second, purity is a crucial theme that reforges the imaginary as society begins to imagine itself as a dirty nest. Catharsis can be achieved only by "cleansing," which, by the way, is genocidal elites' favorite verb. Finally, Semelin discusses the multidimensional concept of security, which can be understood in territorial, cultural, economic, and emotional terms. When these social dimensions come under pressure, radical elites can construct an imaginary of fear and anxiety. They then determine that only the destruction of an (often internal) enemy can neutralize threats. The primary components in the three themes of identity, purity, security are life versus death and existence versus destruction. In times of political crisis, they can appeal to large segments of the population and serve to justify violence against certain groups.

Purify and Destroy is useful for genocide scholars for its analytical structure, which can metaphorically be imagined like a three-pronged Matryoshka doll. This design paradigm can be analyzed at the macro, meso, and micro levels, bearing in mind the relevant connections between the three levels. The macro level refers to interstate structures and the context of geopolitical power relations. The meso level consists of all intrastate developments relevant to the genesis of the political crisis and, later, the genocide. The micro level, then, is about how individuals become involved in the genocidal process either as perpetrators, victims, or third parties. Viewed in its coherence, rather than a pyramid structure, a Matryoshka doll might be a better visualization of a model. These three contextual layers are not simply piled on top of each other, but the largest contexts are conditions for the smallest ones. Without the macro context of interstate crisis, there cannot be an internal radicalization of the political elites; and without that radicalization, the violent measures against the victims would not have been taken and countless individual perpetrators would not have murdered innumerable individual victims in micro situations of killing. If we take this structure as a starting point, there is a lot we know about genocide. In what follows, I shall briefly discuss these three contexts, using recent and forthcoming studies of genocide.

The macro level concerns the international context and structure of geopolitical power relations that could lead to war. It is most often binary international conflicts that escalate into war and (potentially) genocidal situations: Turkey-Greece, GermanyUSSR, Cambodia-Vietnam, Serbia-Croatia, Rwanda-Burundi. During war the main condition for genocide is often met. Violence is already widely exercised, first only between standing armies in legally legitimate military hostilities but later also in criminal para-state operations. One binary axis of tension that has been studied in-depth is that between Nazi Germany and the Soviet Union. Ernst Nolte's 1986 argument that the Nazi genocide was a reaction to Stalinist mass murders (including the Gulag), triggered the Historikerstreit but did not substantially confront the problem of interstate 
polarization. ${ }^{31}$ Conversely, recent research has recognized that their relations, whether rapprochement or antagonism, influenced the course and nature of their violence. Timothy Snyder's mammoth Bloodlands makes the argument that the two regimes wittingly (and unwittingly) "enabled" each other's crimes in the Molotov-Ribbentrop pact. ${ }^{32}$ On the other hand, antagonism unleashed violence of a different nature, which Michael Geyer and Mark Edele paraphrase as follows: "Seen as a totality, the war in the 'East' started with a rapid-fire escalation of unrestraint on the German side ... and was countered by a distinct radicalization and barbarization in the context of defense measures by the Soviets, which in turn triggered a radicalization and barbarization process on the side of the aggressor." 33 These sophisticated studies on the interstate context of mass violence can be replicated in other cases.

Apart from the relations between discrete states, the international state system as a changing, unpredictable constellation needs more attention as well. Before the growth of international and transnational organizations, states often championed humanitarian intervention, while under the surface playing a dirty game of manipulative diplomacy. The Cold War only exacerbated this existing, structural problem as the United States and the Soviet Union fought proxy wars and expressed moral indignation at mass violence opportunistically. Forthcoming research on genocide focuses on Western countries' responses to mass violence in postcolonial states as one dimension of Cold War politics. ${ }^{34}$ Since the 1990s, studies of the role of the United Nations have exposed the organization's inertia in the face of genocide, for example in Rwanda. They have also demonstrated that this apathy (and states' knowledge of it) can even contribute to the commission of genocide. ${ }^{35}$ The politics of the macro level profoundly influence the lower two levels. For example, on 14 July 2008 the International Criminal Court (ICC) in the Hague indicted Sudanese President Omar Al-Bashir on counts of war crimes and crimes against humanity. A year later the ICC issued an arrest warrant for Al-Bashir and indicted him for genocide as well. The Sudanese government retaliated by expelling international aid agencies and intensifying the violence on the ground against Darfuris. ${ }^{36}$ In other words, a well-intended and justifiable act by the ICC inadvertently caused more misery for the victims.

Below the macro level of international relations, the second Matryoshka enters into force. Within the structure of war are nestled intrastate developments such as the ideological self-hypnosis of political elites, complex decision-making processes, the necessity and logic of a division of labor, the emergence of paramilitary troops, and any mass mobilization for the segregation and destruction of the victim group. The inception of genocide is a central problem we need to understand better. Popular myths hold that countries descend into "madness" as people pick up clubs and machetes to batter their neighbors in a violent anarchy. Surely genocide is always organized by political leadership, but we need to recognize as well that generally these enormous processes have surprisingly few practical organizers at the top. For example, Aktion Reinhard murdered approximately two million Jews and was set up by Christian Wirth, Odilo Globocnik, Franz Stangl, and Irmfried Eberl. In the Soviet Union, it was Stalin's inner circle that organized the mass murders: Vyacheslav Molotov, Kliment Voroshilov, Lazar Kaganovich, Andrei Zhdanov, and Nikolai Yezhov. Hundreds of thousands of people were murdered within a year across the huge country upon orders from half a dozen men. So too in the Armenian Genocide. A small group around Talaat Pasha organized the genocide; Dr. Bahaeddin Shakir, Dr. Mehmed Nazım, Ali Münif, Şükrü Kaya, and a few 
fanatical governors wiped out almost the entire Armenian community of the Ottoman Empire.

The decision-making process consists of the initiation of a genocidal policy and further developments. Two assumptions should be avoided. First, one should not search for the order, the decree that authorizes absolute destruction and separates the pre-violent period from murder. Genocide generally develops through radicalizing phases that come as shocks to existing policies. A sophisticated literature exists on this subject in the field of Holocaust history. ${ }^{37}$ Second, political elites do not and cannot always foresee the consequences of the decisions they take. Persecution can develop into expulsion and expulsion can escalate into mass killing, and each shift in policy can be an unintended consequence of the previous one. For example, during dekulakization in 1930-1931 the Soviets deported 1.8 million kulaks (better-off peasants) to Siberia. When tension with Japan grew in the 1930s, the kulaks' presence in the Soviet-Japanese borderlands was seen as an internal liability and many were killed after all to subdue an "insurgent rebellion." In other words, "one repressive policy created the foundation for another." 38 The genocidal process is to some extent an unintended but directional process (a blind process), ${ }^{39}$ and determinism should be avoided.

I will now briefly discuss one important issue relevant to the meso level: regional variation in genocides. Regionalization and de-regionalization are important themes in recent genocide research. Genocide scholars have examined the relationship between central decision-making processes and the implementation of mass murder at the local level. In-depth research on how the genocidal process evolves at the provincial, district, city, or even village level has proven to be a fruitful endeavor. It can teach us a great deal about how local shifts in power dynamics can influence the course and intensity of genocidal processes, some of which, as we know, are more regionally disparate than others. Local political or social elites can anticipate, expedite, intensify, or delay and resist genocidal destruction steered from above. A meso focus can also follow the deterioration and ultimate disintegration of intercommunal relations as a result of external pressures, amidst drastically worsening security conditions for the victims. ${ }^{40}$ These insights at the meso level of the Matryoshka doll illustrate how dynamics within the perpetrator group can account for variation during genocide. They also instruct us that even if genocides unfold on twisted paths, the eventual result is still destruction. It is a desideratum of future research to penetrate deeper into and probe further the complexity of genocides.

Tucked away at the heart of the three Matryoshkas lies the smallest but most venomous doll: the countless killings of defenseless victims carried out by perpetrators. The central question at this level is, How do ordinary people become involved in genocide? Or, to quote Alexander Hinton, "Why did they kill?"41 Comparative research on genocide perpetrators is gradually reflecting common ground and increasing sophistication of this subject. ${ }^{42}$ Horizontal pressure (group conformism), vertical pressure (coercion in a command structure), and routinization are major mechanisms that propel massacre. Genocidal behavior such as sexual violence and cruelty are part and parcel of this level only. Moreover, the interdependence of the macro, meso, and micro levels of genocide runs both up and down: just as the macro context of crisis and war is a precondition for micro-level killings, so too the success of political elites' attempt to destroy a victim group is dependent on the mobilization of perpetrators. The génocidaires need to believe and act in a way that facilitates the genocide as smoothly as possible. Throughout the killing process, they experience an increase in role distance, a development in 
which particular commitments and principles give them the moral integrity to carry out the murders. ${ }^{43}$

One of the cornerstones in the research on rank-and-file perpetrators is undoubtedly Christopher Browning's highly acclaimed Ordinary Men. This powerful study is famous for adopting a socio-psychological model of obedience to authority to explain the behavior of German perpetrators. Browning's research is based on a substantial primary source, records that were housed in the Central Office for State Justice Administrations (Zentrale Stelle der Landesjustizverwaltungen) in Ludwigsburg, near Stuttgart. He benefited from an extensive collection of records that included later interrogations of the perpetrators who carried out the massacres. Browning writes, "Never before had I encountered the issue of choice so dramatically framed by the course of events and so openly discussed by at least some of the perpetrators. Never before had I seen the monstrous deeds of the Holocaust so starkly juxtaposed with the human faces of the killers." ${ }^{4}$ Another example of perpetrator research drawn from the Yugoslav wars is a chapter in Slavenka Drakulićs book, They Would Not Hurt A Fly. ${ }^{45}$ Drakulić uses ICTY hearings to paint a picture of Goran Jelišić, a Bosnian Serb who was known as an ordinary, quiet young man who enjoyed life and liked fishing but who, in 1992, ran a detention center where he tortured and shot possibly hundreds of people. Indeed, he murdered without mercy, without distinction, and without consequences.

What emerges from these studies of perpetrators is a nuanced and complex discussion of dispositional and situational factors. But this is where the research reaches its boundaries. Browning, Waller, Welzer, Drakulić, and others have studied different genocides but reached remarkably similar conclusions, which has become a solidified commonplace in genocide research: anybody can become a perpetrator under the "right" conditions. The Milgram experiments, ${ }^{46}$ which offered a psychological underpinning of this thesis, have been replicated and have apparently yielded uniform results across societies. However, there are grounds to question this established wisdom. Recent research has focused on differences in empathy among human beings. ${ }^{47}$ Some people are equipped with lower levels of empathy at birth, and some people are able to "switch off" their empathy with other people (including victims) better than others. Both of these arguments on disposition have consequences for the study of genocide. Based on a more controlled replication of Milgram's experiments, the psychologist Jerry Burger has argued, "Participants who were high in empathic concern expressed a reluctance to continue the procedure earlier than did those who were low on this trait." ${ }^{8}$ The societal dehumanization that accompanies the genocidal process, then, cannot but further exacerbate this and render individuals more susceptible to the process of genocide perpetration. Forthcoming research will hopefully flesh out this problem and offer more complex answers. ${ }^{49}$

This Matryoshka model with its three levels of analysis can be seen as a set of complex processes that trigger the initiation and execution of mass political violence. The levels roughly correspond to academic disciplines: whereas political scientists study the macro level, sociologists may be more interested in the intrastate meso level, and the micro level is perhaps an object of study within the domain of psychology. Genocides can best be seen as a complex interplay of developments in this three-tier structure. The model is by no means meant to be an exhaustive evaluation or comprehensive research program but merely a model for possible future research into relevant new directions in genocide research. 


\section{Conclusion: Grapes and Wrath}

Comparative research can be a rewarding and meaningful effort, but without models or theories research on genocide quickly reaches its limits. Without a theoretical perspective or a modicum of conceptualization, there is a risk of tracing only superficial similarities rather than delving deeply into parallel biographies, analogous structures, and similar developments. Empirical density cannot substitute for clear reasoning. Digging for and locating relevant evidence is important, but the materials must be sufficiently integrated into a study as a whole. In other words, not only do the grapes have to be picked, but the juice of the grapes must be fermented in order to create wine.

Finally, the consequences of genocide cannot be captured in the happy endings characteristic of Hollywood. (Perhaps this is why Hollywood has never produced a single film on genocide with a fairly realistic plot.) The rule is not rescue and escape into freedom, but denial and impunity. Even worse, the consequences of traumatization and victimization can potentially lead to more violence and (cycles of) revenge. Studies of genocides often (rightfully) draw sharp dividing lines between "perpetrators" and "victims" and lock these immutable roles at that particular segment in history. ${ }^{50}$ But humans' potentially multiple roles in genocidal processes are often overlooked or ignored. ${ }^{51}$ Moreover, survivors and victim communities are too often patronized as having drawn universalist humanist lessons from their victimization and are often expected to forgive and "reconcile," a deeply problematic concept. On the contrary, victimized individuals and groups often feel vindictive (with or without justice) and can call for vengeance as a justified response to victimization. Political elites often capitalize on desires of vengeance among victim groups. Once mobilized, when such a process of collective vengeful desire escalates and crosses the threshold of violence, we are back to square one.

Uğur Ümit Üngör is Assistant Professor of History at Utrecht University and at the Institute for War and Genocide Studies in Amsterdam. His main area of interest is the historical sociology of mass violence. His publications include The Making of Modern Turkey: Nation and State in Eastern Anatolia, 1913-1950 (Oxford University Press, 2011) and Confiscation and Destruction: The Young Turk Seizure of Armenian Property (Continuum, 2011).

\section{Notes}

1. Rudolph J. Rummel, Death by Government (New Brunswick, NJ: Transaction, 2009), 4.

2. For a comparative discussion of various definitions of genocide, see Adam Jones, Genocide: A Comprehensive Introduction (London: Routledge, 2006), 12-23.

3. Raphael Lemkin, Axis Rule in Occupied Europe: Laws of Occupation, Analysis of Government, Proposals for Redress (Washington, DC: Carnegie Endowment for International Peace, 1944), 79-95.

4. For three recent volumes on the state of affairs in the research field, see Dan Stone, ed., The Historiography of Genocide (Basingstoke: Palgrave Macmillan, 2008); Samuel Totten and Paul R. Bartrop, eds., The Genocide Studies Reader (New York: Routledge, 2009); Donald Bloxham and A. Dirk Moses, eds., The Oxford Handbook of Genocide Studies (Oxford: Oxford UP, 2010).

5. Christian Gerlach, "Extremely Violent Societies: An Alternative to the Concept of Genocide," Journal of Genocide Research 8,4 (2006): 455-71.

6. Norbert Elias, "Problems of Involvement and Detachment," British Journal of Sociology 7,3 (1956): 226-52.

7. Kathleen E. McLaughlin, "Iris Chang's Suicide Stunned Those She Tried So Hard to Help," San Francisco Chronicle, 20 Nov 2004, E1.

8. Robert J. Lifton, The Nazi Doctors: Medical Killing and the Psychology of Genocide (New York: Basic Books, 1986), 12.

9. Roy Schafer, "Generative Empathy in the Treatment Situation,” Psychoanalytic Quarterly 28 (1959): 34273; Marco Iacoboni, Mirroring People: The Science of Empathy and How We Connect with Others (New York: Picador, 2009), 6ff. 
10. Land of Our Grandparents, directed by Alexander Goekjian and Kay Mastenbroek (Zelović Productions, 2008). The film aired on Dutch public television on 24 Apr 2008 and won the prize for best documentary at the Pomegranate Film Festival in Toronto in 2009.

11. For a discussion, see Wendy Doniger, Homo Ludens and Gallows Humor about the Holocaust and Terrorism (Amsterdam: Prometheus, 2001).

12. For an excellent discussion, see Roy F. Baumeister, Evil: Inside Human Violence and Cruelty (New York: First Owl, 2001), 60-96.

13. The Most Evil Men and Women in History, Channel 5, aired 8 Apr 2002-17 Jun 2002 (GB Ulden Associates, 2002),

14. Miranda Twiss, The Most Evil Men and Women in History (London: O'Mara, 2002), back cover copy.

15. Ibid.

16. Ibid. Another book even carries the word "evil" twice in its title: Rodney Castleden, The World's Most Evil People: The Epitome of Evil (London: Futura, 2006).

17. Simon Sebag Montefiore, Monsters: History's Most Evil Men and Women (London: Quercus, 2008).

18. See, e.g., a study of the British media on Yugoslavia: Gregory Kent, Framing War and Genocide: British Policy and News Media Reaction to the War in Bosnia (Cresskill, NJ: Hampton, 2006).

19. Godfried van Benthem van den Bergh, De Staat van Geweld en Andere Essays (Amsterdam: Meulenhoff, 1980), 37-46.

20. Claudia Weber, "The Export of Terror: On the Impact of the Stalinist Culture of Terror on Soviet Foreign Policy during and after World War II," Journal of Genocide Research 11,2/3 (2009): 285-306.

21. Peter Galbraith, "Richard Holbrooke: A Force for Good," The Guardian, 14 Dec 2010, www.guardian.co. $\mathrm{uk} /$ commentisfree/cifamerica/2010/dec/14/richard-holbrooke-dayton-bosnia (accessed 10 May 2011).

22. Carla Del Ponte, Madame Prosecutor: Confrontations with Humanity's Worst Criminals and the Culture of Impunity (New York: Other Press, 2009), 204.

23. For an overview of the scholarship, see Uğur Ümit Üngör, "Fresh Understandings of the Armenian Genocide: Mapping New Terrain with Old Questions," in New Directions in Genocide Research, ed. Adam Jones (London: Routledge, 2011).

24. Jean-Michel Chaumont, La concurrence des victimes : Génocide, identité, reconnaissance (Paris: La Découverte, 1997), 9-10.

25. Marko Attila Hoare, "Genocide in the Former Yugoslavia: A Critique of Left Revisionism's Denial," Journal of Genocide Research 5,4 (2003): 543-63.

26. For a polemical argument, see Edward Herman, David Peterson, and Noam Chomsky, The Politics of Genocide (New York: Monthly Review Press, 2010).

27. Robert M. Hayden, "Schindler's Fate: Genocide, Ethnic Cleansing, and Population Transfers," Slavic Review 55,4 (1996): 727-48, 732.

28. For a recent study dealing with this aspect, see David Bruce MacDonald, Identity Politics in the Age of Genocide: The Holocaust and Historical Representation (London: Routledge, 2008).

29. Victor Hugo, quoted in Theodore Peterson, "Turkey and the Armenian Crisis," Catholic World 61,365 (Aug 1895): 665-76, 667.

30. Jacques Semelin, Purify and Destroy: The Political Uses of Massacre and Genocide (London: Hurst, 2007).

31. Ernst Nolte, "Die Vergangenheit, die nicht vergehen will," Franfurter Allgemeine Zeitung, 6 Jun 1986.

32. Timothy Snyder, Bloodlands: Europe between Hitler and Stalin (London: Bodley Head, 2010), 318.

33. Mark Edele and Michael Geyer, "States of Exception: The Nazi-Soviet War as a System of Violence, 1939-1945," in Beyond Totalitarianism: Stalinism and Nazism Compared, ed. Michael Geyer and Sheila Fitzpatrick (Cambridge: Cambridge UP, 2009), 350.

34. A. Dirk Moses, The Diplomacy of Genocide: A Study of the International Community's Reaction to Genocide (forthcoming).

35. Alan J. Kuperman, "Transnational Causes of Genocide, or How the West Exacerbates Ethnic Conflict," in Yugoslavia Unraveled: Sovereignty, Self-Determination, Intervention, ed. Raju G.C. Thomas (Lanham, MD: Lexington, 2003), 55-85.

36. Eric Reeves, "Turning up the Heat in Darfur," The Guardian, 17 Jul 2008.

37. See, e.g., Christopher R. Browning, The Origins of the Final Solution: The Evolution of Nazi Jewish Policy, September 1939 - March 1942 (Lincoln: U of Nebraska P, 2004).

38. Snyder, Bloodlands, 80 .

39. For a discussion, see Norbert Elias, "Zur Grundlegung einer Theorie sozialer Prozesse," Zeitschrift für Soziologie 6 (1977): 127-49.

40. Examples of innovative local studies of genocide are: Tomislav Dulić, Utopias of Nation: Local Mass Killing in Bosnia and Hercegovina, 1941-42 (Uppsala: Uppsala UP, 2005); Wendy Lower, Nazi Empire- 
Building and the Holocaust in Ukraine (Chapel Hill, NC: U of North Carolina P, 2005); Lee Ann Fujii, Killing Neighbors: Webs of Violence in Rwanda (Ithaca, NY: Cornell UP, 2009); François-Xavier Nérard, "The Levashovo Cemetery and the Great Terror in the Leningrad Region," Online Encyclopedia of Mass Violence, 27 Feb 2009, http://www.massviolence.org/The-Levashovo-cemetery-and-the-Great-Terror-inthe (accessed 10 May 2011).

41. Alexander Laban Hinton, Why Did They Kill?: Cambodia in the Shadow of Genocide (Berkeley: U of California P, 2005).

42. Olaf Jensen and Claus-Christian Szejnmann, eds., Ordinary People as Mass Murderers: Perpetrators in Comparative Perspectives (London: Palgrave Macmillan, 2008).

43. Harald Welzer, Täter: wie aus ganz normalen Menschen Massenmörder werden (Frankfurt am Main: Fischer, 2005); James Waller, Becoming Evil: How Ordinary People commit Genocide and Mass Killing (New York: Oxford UP, 2002).

44. Christopher R. Browning, Ordinary Men: Reserve Police Battalion 101 and the Final Solution in Poland (New York: HarperCollins, 1992), xvi.

45. Slavenka Drakulić, They Would Never Hurt A Fly: War Criminals on Trial in The Hague (New York: Viking, 2004), 66-82.

46. Stanley Milgram, Obedience to Authority: An Experimental View (New York: Harper \& Row, 1974).

47. Roy F. Baumeister, Evil: Inside Human Violence and Cruelty (New York: Henry Holt, 2001), $245-8$.

48. Jerry M. Burger, "Replicating Milgram: Would People Still Obey Today?," American Psychologist 64,1 (2009): 1-11.

49. Abram de Swaan, Regression in the Service of the State: The Microsociology of Genocidal Behavior (forthcoming).

50. The classic study was Raul Hilberg, Perpetrators, Victims, Bystanders: The Jewish Catastrophe, 19331945 (New York: HarperCollins, 1993).

51. One example are the Cambodian "victim-perpetrators." See Meng-Try Ea and Sorya Sim, Victims and Perpetrators?: Testimony of Young Khmer Rouge Comrades (Phnom Penh: Documentation Center of Cambodia, 2001). 